\title{
Ontology of Public Health in University Curriculum: Exploring Basic Elements of an Interdisciplinary Field of Knowledge
}

\author{
Zahirul Islam (Corresponding author) \\ Department of Anthropology, Session 2013-14, PhD Course \\ Jahangirnagar University, Savar, Dhaka 1342, Bangladesh \\ E-mail: zislam008@gmail.com
}

$\begin{array}{ll}\text { Received: December 21, } 2016 & \text { Accepted: May 3, } 2017 \quad \text { Published: May 8, } 2017 \\ \text { doi:10.5296/jei.v3i1.10478 } & \text { URL: https://doi.org/10.5296/jei.v3i1.10478 }\end{array}$

\begin{abstract}
Public health has constituted itself as a distinct academic discipline. The present paper attempts to understand ontology of this discipline. A study has recently been carried out which concerns, first, conceptualization of ontology of public health, secondly, nature of public health, and thirdly, curriculum development. Ontology is a philosophical doctrine that refers to an understanding about the basic elements theorized about. As the paper unveils, the tenet of public health is that the health state is not a matter of 'individual' only; rather this is a question of the 'collective' too. Diverse aspects take forms of intellectual construction which are transformed into the subject of the discipline. They are categorized as worldview, theory, methodology, instrumentation, and application. The constructions are internalized in the discipline's nature to be 'epistemic', 'interdisciplinary' and 'componential'. In order to produce knowledge, the discipline involves an epistemic process consisting of priori and posteriori approaches. Public health, though the prevailing thoughts and practices are derived from biomedical paradigms, contains an interdisciplinary trait that draws from the fields of formal, organic, inorganic and social sciences. The discipline comes to be appeared as an integral whole being componential. The aforementioned categories of intellectual constructions are viewed as the basic elements of public health. Elements exist and operate in a center/periphery binary relationship. Center (worldview), while it holds the whole structure of the discipline together, limits the movement of rest elements and keeps them in the periphery. The paper concludes by pointing out few issues for developing curriculum for universities.
\end{abstract}

Keywords: Public health, Ontology, Reality, Worldview, Theory, Methodology, 
Instrumentation, Application

\section{Introduction}

An interaction between two languages - language of researchers and language of respondents - happens in a research process ... Exact situations and hidden voices of community can't be transformed into research findings.

These lines are cited from author's article which was selected for the $6^{\text {th }}$ Qualitative Health Research Conference at the University of Alberta (Islam, 2000, p. 1). The question about the quality of public health research raised in the article is ascribed to ontology. Public health, over the last 200 years, has constituted itself as an academic discipline that deals with the health of people in general (Shattuck, 1850; Afifi \& Breslow, 1994). It aims to produce, reproduce, distribute and apply knowledge so as to promote the health state. Not only did a plethora of public health endeavors establish 'health' as a notion by making its relationship with the notion 'public', this also took a huge aspect of health, ranging from the molecular to the ecosystem level, into attention. But how exactly can questions of public health be addressed? It is a concern of ontology of public health, which remains a rather unexplored question. A realization of the works of Institute of Medicine (IM) (1988), Krug and Hepworth (1997), Kreiger and Brin (1998), Godfray (2013), and Martin-Moreno (2015) is that the approach of public health needs to be expanded, multipronged and sustainable. The probability of any intended development of an academic discipline lies in the nature of that discipline. Few works (e.g. Nijhuis \& van der Maesen, 1994; Beauchamp, 1995; Cole, 1995; Weed, 1999; van der Maesen \& Nijhuis, 2000; Rudnick, 2004) attempted to provoke conversations on the philosophical foundations of this academic discipline. These writings find the importance of ontology to unveil underpinnings of public health.

The idea 'ontology of public health' in this study has been derived from the understanding that treats ontology as a taught course rather than a subfield of public health. An important fact is ascribed to this study that the higher education institute - for instance, department of public health and informatics at Jahangirnagar University (Bangladesh) - has included ontology of, and epistemology of public health in the curriculum. The higher education lets the students have deeper knowledge into the subject area then attempt to reproduce knowledge aiming to gain expertise in producing and applying knowledge (Becher \& Trowler, 2001; Forest \& Kinser, 2002). This achievement is not possible without insightful understandings of ontology since a field of knowledge is grounded and funded on ontology. Thus, ontology extends scope to the learners to be exposed to root and formation of the body of public health knowledge. They gain intellectual capacity in unveiling inter-, and intrarelationships of such elements. Besides, a trend that the signifier (the form of a sign) refers directly to the signified (the content of a sign), has passed down a whole current of logocentric (speech-centered) thought that originated in the time of Plato (Guillemette \& Cossette, 2006). The ontological approach also reinforces rethinking of the metaphysical history of public health with its hierarchies and dichotomies that have survived to this day, the foundation upon which all of logic (logos, which means language) constructing univocal meanings were laid. This approach, most significantly, goes with a lens examining whether 
the public health knowledge reveals health situation 'as it really is'. Thus, ontology concerns the very foundation of academic discipline.

The aim of the present paper is to understand ontology of public health. Though there are many ways to understand it, the paper concerns three aspects which include conceptualization of ontology of public health, nature of public health and development of curricula. What does ontology mean in the case of viewing it from the perspective of public health? Why is ontology important? Why is it intrinsic to the curriculum? What is the nature of public health as a distinct field of knowledge and how ontology unveils it? How can the curriculum on ontology be developed? A study has recently been carried out dealing with such questions. This paper is the result of that study. The first section of the paper describes how this study took place, what methods and procedure were followed. Then the paper attempts to conceptualize 'ontology of public health'. It is a concept that consists of four separate concepts: 'ontology', 'public', 'health', and 'public health'. The study unveils the nature of public health to be 'epistemic', 'interdisciplinary' and 'componential'. These are elaborated in the third section. 'Epistemic' relates to knowledge; 'interdisciplinary' involves the combining of more academic disciplines; and 'componential' stands for the analysis of the different elements. The paper concludes by recommending suggestions to developing curricula for universities.

\section{The Study}

The study draws on a systematic review (SR) that was carried out from January to December 2016 focusing on the questions mentioned in section 1. In order to extract substance of the best available materials, the SR has been done by synthesizing the results of these. By 'materials' this study refers to both published and unpublished written texts and documents relevant, explicitly and implicitly, to research questions and aims which include journal articles, research papers, textbooks, reports, monographs, commentaries, editorials, dictionaries, encyclopedias, policy papers, conference proceedings, syllabus, curriculums, handouts and reading materials. Research questions and aims (stated above) were considered as main criteria for selecting materials. Texts and documents were searched which were accessible to the author. Libraries and websites of international and local institutes academic, research and service providing - were explored. A transparent and bias free procedure to find, evaluate and synthesize the results of relevant literature has been followed by involving (a) clear inclusion/exclusion criteria, (b) an explicit search strategy, (c) systematic coding and analysis of included materials, and (d) meta-analysis. Materials included in the review were screened for quality so that the findings of a large number of materials can be combined. In addition, the article internalized author's personal learning from and experience of teaching ontology at the Department of Public Health and Informatics, Jahangirnagar University, Bangladesh since early 2016.

\section{Conceptualizing Ontology of Public Health}

The materials, drawn to conceptualize ontology of public health in this paper are related to several aspects: the issue of philosophy, notions of 'ontology', 'public' and 'health', and definition of 'public health'. Philosophy encompasses everybody of knowledge, academic 
discipline (Becher \& Trowler, 2001; Grayling, 2001; Rudnick, 2004). There is no academic discipline that can be existed and progressed unless it is underpinned by philosophy since the aim of philosophical inquiry is to gain insight into questions about knowledge, truth, reason, reality, meaning, mind, and value (Grayling, 1998). Though ontology belongs to the academia as a branch of philosophy accompanied by epistemology, aesthetics, and ethics, it is not a discipline that exists separately and independently from all the other scientific disciplines. 'Ontology of public health' does not belong to glossary and encyclopedia and even is extrinsic to professional vocabulary. The term contains a unit of definite meaning. However, it is a compound concept, rather than a simple one, that is made up of four distinct concepts 'ontology', 'public', 'health' and 'public health'. Each of them further has a lot of meanings and definitions. Therefore, every concept has to be dealt before going with 'ontology of public health'.

\subsection{Ontology}

Besides linguistic meaning, this study looks at the relationship of ontology with metaphysics and interpretation of ontology in different writings. Indeed a purpose of the author in investigating the materials is to point the ways how ontology is conceived, to determine the underlying thoughts, and to consider the ways in which ontology is thought within the public health disciplinary framework. Etymologically the English noun 'ontology' - it derives from modern Latin ontologia (c. 1600) - consists of onto- and -logy (Harper, 2001). Onto came from Greek that stands for 'a being', 'individual', 'being', 'to be', 'existence'. 'Logos' is usually interpreted as 'science' or 'study'. In his Etymological English Dictionary, Bailey (1721) defined ontology as 'an account of being in the abstract'. Therefore, etymologically ontology refers to the science or study or account of 'being' or 'to be' or 'existence' in the abstract. Its two definitions in a current Oxford dictionary include (i) dealing "with the nature of existence"; (ii) "a list of concepts and categories in a subject area that shows the relationships between them" (Hornby, 2010, p. 1064).

A discussion is often found in several texts (e.g. Hill, 1822-1907; Audi, 1999; Simons, 2017) that is pervaded by viewing ontology as equated to metaphysics. But both notions are distinctive from each other in terms of their origin, worldview, signification and subject matter. Indeed, this distinction would extend understanding of ontology. Metaphysics came into usage in the $1^{\text {st }}$ century B C to denote a part of the philosophical heritage of Aristotle (Frolove, 1984) while the term ontologia 'ontology' was coined by J. Lorhard in the early $17^{\text {th }}$ century to understand contemporary worldview in Europe (Lamanna, 2006). Øhrstrøm, Schärfe, and Uckelman (2008) quotes from Timpler (1604, p. 635), 'the subject-matter of metaphysics is not being, but rather the intelligible. Metaphysics is a contemplative art which treats of every intelligible, to the extent that it is intelligible by men through the naturalist worldview that is natural light of reason without any concept of matter'. According to Comte, evolution of human thoughts has undergone three stages of increasing objectivity (Pickering, 2006). At first, realities were explained as the outcomes of the arbitrary actions of supernatural power. Then humans became intelligent enough to formulate metaphysical abstraction. Finally, human thought achieved the third stage - the world was explained in terms of scientific truth - in which ontology emerged. 
As inferred from the works (for example, Timpler 1604; Lamanna, 2006; Pickering, 2006; Øhrstrøm, Schärfe, \& Uckelman, 2008), the concept 'ontology' itself invokes an understanding that ontology is a distinct philosophical enterprise. Subject matter is the nature of reality, the basic elements of reality and their relations. Particularly, it interests the questions concerning what realities exist or may be said to exist and how such realities are categorized. The enterprise involves a cognitive as well as intellectual process through which reality and its various elements are transformed from 'concrete' into 'abstract' then turn into basic elements of a specific field of knowledge. Therefore, prime concerns of ontology are: firstly, to study the nature of reality; secondly, to transform realities through abstraction into basic elements of knowledge.

A relevant but inevitable question is how does the paper conceptualize reality? An Oxford Dictionary (Hornby, 2010) denotes the term reality, firstly, as 'the true situation and the problems that actually exist in life in contrast to how you would like life to be '. Secondly, as 'a thing that is actually experienced or seen, in contrast to what people might imagine'. There are several notions e.g. fact, the real world, real life, actuality, truth, existence, 'being', 'to be', 'becoming', 'existence', 'essence', and 'entity' (Bailey, 1721; Hill, 1822-1907; Audi, 1999; Harper, 2001; Simons, 2017), which are observed to connate meanings that are the same or nearly the same to reality. Referring to Øhrstrøm, Schärfe, and Uckelman (2008), Luchte (2007) and Critique of Pure Reason (2017) reality from the perspective of ontology stands for 'intelligible reality' that includes two different fundamental types of representations. These are: mediate representations of reality that take form of concepts; and immediate representations which are manifested in intuitions. A concept represents reality or a thing of reality by representing general characteristics of reality. On the other hand, intuition represents reality directly in three ways: (i) without containing any sensation which is called as pure representation. (ii) Empirical intuitions - in this way representation needs to contain sensation. (iii) Collation that internalizes both pure and empirical representations.

\subsection{Public and Health}

As materials from linguistic, philosophical, sociological and biomedical perspectives evidence, the ways by which 'public' comes to be the concept deploys binary relationship. The units of representation have meaning by the means of binary opposition; each unit is defined against what it is not. Everything is organized into a hierarchical structure; concepts are related to positives or negatives, with no apparent latitude for deviation (Fogarty, 2005). The concept presents itself with 'others', from and with which it distinguishes and contrasts itself. There are several 'others' as parts of binary with public, e.g. private, personal, special and individual. The meaning of public is created by situating it in a binary relationship with any of these others that it is not. However, the word 'public' originated with the Latin publicus (also poplicus) from populus denoting 'some mass population' ('the people') in association with some matter of common interest (Lewis \& Short, 1879). As noun, adjective and adverb simultaneously the Oxford dictionary (Hornby, 2010) retains several meanings like 'ordinary people', 'for everyone', 'of government', 'group of people'. According to Dewey (1927) a philosophical notion that public is a group of people who, in facing a similar problem, recognize it and organize themselves to address it. From the sociological 
perspective, Nijhuis and van der Maesen (1994) views public as the outcome of interactions between individual human beings. A biomedical meaning of 'public', defined by Shattuck (1850) and Center for Disease Control and Prevention Foundation (CDCF, 2016), is the 'entire populations'. Hence, public is understood as an entity that is comprised of individuals who belong to one or more relationships with each other appearing in different forms: family, community, clan, peerage, class, generation, population and species.

Sources including Lewis and Short (1879), Harper (2001) and Hornby, (2010) in interpreting 'health' - it originated from Old English hoelp - are anonymous about these meanings: wholeness, a being whole, sound or well, uninjured. Cartesian dualism, a trend that involves psychosomatic view - 'body-mind' dichotomies (Kirmayer, 1988) between realities of human life, is observed in medical science to understand the concept health. Realities are further categorized creating the binary relationship of normal/abnormal where the health belongs to normality and disease is to abnormality (Murphy, 1973). Normal is brought to represent an ideal state which is viewed as healthier and better situation than 'abnormal'. Statistical average or the most common typical characteristic of health is theoretically a rational ideal. According to Murphy (1973), the standard value of physiological functionality or meet requirements of the person also is ascribed to the idea of normal. Health definition offered by the World Health Organization (WHO) in 1948 understands the normality as a state of complete physical, mental and social well-being. This definition - it is widely accepted - lets health to be the totality of human well-being by internalizing physical, mental and social. The existence of disease or infirmity in human body is recognized as intrinsic. Accepting this definition taken-for-granted, not only does a plethora of public health literature view health and disease as phenomena of 'private' individuals, it also brings them to the 'public' arena.

\subsection{Public Health}

Public health' is not a homogenous concept rather it is observed to be understood in a variety of ways. In obtaining the state of health, the American Health Association emphasizes the importance of public health and places human life's realities in four relational levels: mortality, serious morbidity, minor morbidity and positive health (Jones, Shainberg, \& Byer, 1985). The definition proposed by Winslow (1920) about one century ago is distinctive and explicit for this reasons that it internalizes notions of public health simultaneously as science and art. Three functions that they perform include preventing disease, prolonging life and promoting health. Organized efforts and informed choices of society, organizations, public and private, communities and individuals are brought as means of doing. However, the paper draws on aforesaid concepts of ontology, public and health, and looks at a few relevant writings (e.g. Shattuck, 1850; Winslow, 1920, 1926; IM, 1988; Cole, 1995; Beauchamp, 1995; Kreiger \& Brin, 1998; Weed, 1999; CDCF, 2016; Turnock, 2016; WHO, 2016) to explore the concept of 'public health'. At least three intertwined notions of public health (i) as reality, (ii) as service and (iii) as academic discipline are found to appear. As 'reality' public health is understood as the facts related to health in everyday lives, while 'service' refers to the measure protecting and improving health. As 'academic discipline' it aims to produce, reproduce, distribute and apply knowledge of such reality and measure. Nevertheless, in few questions the three notions of public health stand in the common place. The focus of these 
notions is 'all humans'. A tenet is put in the center that disease, illness and health are not matter of 'individuals' only; rather these are caused and reinforced by the 'collectives' too, that is 'public'. The notions generally view both normality and abnormalities as parts of the health state. Besides scientific knowledge, different values, policies, and practices are embodied towards full inclusion of people with diverse backgrounds.

\subsection{Ontology of Public Health}

As mentioned above (section 3.1), ontology is a distinct philosophical enterprise which comes to be used as the philosophical doctrine in academic discipline. Hence, the paper draws an inference of concept of ontology of public health that it is 'a philosophical doctrine that refers to an understanding about the basic elements theorized about; of public health'. Here public health comes to be understood as a modern scientific academic discipline internalizing concepts of public health as reality and as service. Doctrine, from Latin doctrina, is brought here to mean "a body of teachings" or "instructions", taught principles or positions, as the body of teachings in a branch of knowledge or belief system (Harper, 2001; Hornby, 2010). A philosophical doctrine internalizes a principle or set of principles laid down by an authority as incontrovertibly true. Understanding basic elements requires detailed discussion what the paper intends.

\section{Basic Elements of Public Health}

The materials, including the works of, such as, Winslow (1920), Jones, Shainberg, and Byer (1985), Afifi and Breslow (1994), Cole (1995), Nijhuis and van der Maesen (1994), Beauchamp (1995), Krug and Hepworth (1997), Bhopal (1999), Weed (1999), van der Maesen and Nijhuis (2000), Earle, Lloyd, Sidell, and Spurr, 2007, Dawson (2009), Gifford (2011), Howick (2011), Guest, Ricciardi, Kawachi, and Lang, 2013, Park (2013), Muthu (2014), and Turnock (2016), which have been reviewed in this study with intent to reveal the nature of the public health evidence that aspects are transformed to the subject matters of the study. It's not possible to spell every aspect out in detail, but it could generally be said that all of these are claimed to be related to problems in the public health field including the ways to define and solve the problems. However, the subject matters take the forms of intellectual constructions, e.g. presumption, idea, notion, concept, schema, model, proposition, inference and prediction. In order to expound the constructions this study puts them into five categories, which could be named as 'worldview', 'theory', 'methodology', 'instrumentation' and 'application'. Indeed, these constructions are considered in the study as basic elements as well as building blocks which underlie the structure of the public health discipline. Besides, they are internalized in the discipline's nature to be 'epistemic', 'interdisciplinary' and 'componential'.

'Epistemic' nature refers that since public health is an academic discipline it inevitably takes a form of knowledge. The discipline involves an epistemic approach consisting of priori and posteriori processes. The priori stands for innate knowledge that is 'prior to experience and the posteriori refers to the empirical knowledge (Luchte, 2007). Human cognitive faculties have the role in structuring the known and knowable world. Priori intuitions and concepts provide some priori knowledge, which also provides the framework for a posteriori 
knowledge. Hence knowledge is constituted by the collation of preexisting concepts within the mind and information gained through the senses.

'Interdisciplinary' is the innate nature of public health that lets the discipline to extract 'knowledge' from many other fields. This means the involvement of the combination of several academic disciplines into one subject area (Ausburg, 2016). Public health, though the prevailing thoughts and practices are derived from biomedical paradigms, draws from the fields of formal, organic, inorganic and social sciences. The article, referring to Winslow (1926), Guest, Ricciardi, Kawachi, and Lang (2013), Park (2013), Muthu (2014), Warren and Smalley (2014), Turnock (2016), observes public health to be a distinct interdisciplinary field which crosses traditional boundaries between above academic disciplines and various schools of thought. Thus, 'knowledges of different fields' are transformed into the 'knowledge of public health'.

The public health discipline comes to be appeared as an integral whole while being componential. As mentioned above (section 4), five categories of intellectual constructions, i.e. worldview, theory, methodology, instrumentation, and application are viewed as the basic elements of public health. The body of knowledge in a given discipline consists of such elements which can be taken apart for study and separately verifiable (Hatch \& Barclay-McLaughlin, 2006). How they happen and exist as basic elements within the disciplinary border and how they operate towards discipline's aim will be explained below. The paper mentioned earlier (section 1) that the aim of public health is to produce, reproduce, distribute and apply knowledge so as to promote the health state. The discipline posited worldview in the center, i.e. a point from which each of rest of the elements (theory, methodology, instrumentation, and application) comes and to which every element refers (Klages, 2007). The elements, thus, happen, exist and operate in a center/periphery binary relationship. The center, while it holds the whole structure of the discipline together, limits the movement of the rest of the elements and keeps them in periphery.

\subsection{Worldview}

There are universal principles behind the thoughts in every field of knowledge that put it in a worldview which is a philosophical premise (Gifford, 2011; Howick, 2011). Worldview is often defined in lexicology as belief and notion of what world is and way of looking at world. The scale of the universe mapped to the branches of science offered by R. Feynman depicts a world (Feynman, Leighton, \& Sands, 2013). Taking human to the center ( $\varnothing \varnothing$ in meter), this world includes the things ranging from particle $\left(10^{-15} \varnothing\right)$ to visible universe $\left(10^{27} \varnothing\right)$. Origins of modern sciences and modern public health are synchronic and syntopic facts. The project of modernity in Europe of the $17^{\text {th }}$ and $18^{\text {th }}$ centuries as had been promoted led to rapid scientific advancement especially in microbiology. In the same time and same spatial location modern public health was being emerged as a social service to control communicable diseases being grounded in science (Afifi \& Breslow, 1994; Turnock, 2016). Hence, as the paper unveils, the worldview of public health is derived simultaneously from two sources - the philosophy of science and the tenet of disease, illness and health. This worldview is an integral part of the scientific paradigm by ascribing to a positivist worldview (Kreiger \& Brin, 
1998; Dawson, 2009; Turnock, 2016). World can be known solely through observation and reason. According to Pickering (2006), Comte dedicated the positive philosophy to "Joseph Fourier and Blainville, both of whom had been a source of personal encouragement and exemplified the positive spirit in the inorganic and organic sciences respectively" (p. 561). Positive philosophy thus represents a way of reasoning which has been applied to all scientific disciplines.

The pursuit of scientific knowledge - its way of thinking about and understanding reality seems to be commonly justified by locating it in either of two global inferences: first, human history as emancipation (Hughes \& MacNaughton, 2000). This is a political perspective associated with the French Enlightenment in the $17^{\text {th }}$ century through the end of the $18^{\text {th }}$ century legitimated by the presumption of a universal freedom. For Kant, the Enlightenment was mankind's final coming of age, the emancipation of the human consciousness from an immature state of ignorance (Luchte, 2007). Secondly, human history as the (scientific) realization of reason: this is a philosophical perspective associated with German idealism in the late $18^{\text {th }}$ and early $19^{\text {th }}$ centuries legitimated by the presumption of a universal knowledge. Thus the worldview of public health is underpinned by the philosophy of science that is the positivist worldview (Lindberg, 2007). This philosophy presumes that (i) there is an objective world shared by all rational observers; (ii) this world is governed by natural laws; (iii) these laws can be discovered by means of systematic observation and experimentation. Indeed, these are inferences about the nature of reality in the world based on which public health administers investigation for acquiring new knowledge, or correcting and integrating previous knowledge. As mentioned above (section 3.3), the central tenet of public health lets the state of health to be caused and reinforced by the 'public' rather than considered as a matter of 'individual' only. Therefore, the standpoint is that such state can be captured, changed and diverted, even constructed and reconstructed, by the 'public' measure. There are no public health problems behind or beyond what can be known and solved by applying public health knowledge.

\subsection{Theory}

Public health requires to possess and develop the structured pathways and laws to deal with issues in its subject area. Such pathways and laws are understood as theory which facilitates explaining, predicting and intervening (Halvorson, 2012). Theories are deployed in explaining why and how things occur and exist, predicting what is going to happen, and choosing ways to make things turn out in desired ways. A binary relationship of theory with practice is in operation here. Theory involves trying to understand the causes and nature of health, disease, and illness, while the practical side of medicine is trying to make people healthy. Yoshinori Ohsumi, a Nobel laureate in 2016, discovered how cells recycle their content - a process known as autophagy (self-eating) (Gilman, 2017). This discovery adds itself as a theory to the public health field.

Two aspects extend understanding of theory in the study. They include, first, distinction between theory and philosophy, secondly, relationships of notion, concept, and proposition with theory. Philosophy interests the theoretical basis of a particular branch of knowledge and 
theory is intrinsic to philosophical premise. Both deal with the problems which concern the nature of existence, knowledge, morality, reason and human purpose (Teichmann \& Evans, 1999). Nevertheless, these are not exactly the same. While theory draws on both priori and posteriori knowledges, philosophy derives mainly from priori knowledge. A theory, for instance, the multi causes of disease theory (M. Susser \& E. Susser, 1996), is a well-substantiated explanation of etiology. This explanation is based on facts that have been repeatedly confirmed through rational, observation and experiment.

This study, referring to Reynolds (1971), Godfrey-Smith (2003), Earle, Lloyd, Sidell, and Spurr (2007), Klages (2007), Dawson (2009), contends that notion, concept and proposition are interrelated and inevitable parts of the theory. Notion and concept - each of them is understood as an idea that is abstract having a binary relationship with real. An 'inductive/deductive' method proceeds either 'from real to abstract' or 'from abstract to real' (Williams, 1991). Concept is the mediate representation distinguished from intuition which is the immediate representation. Reality is represented by concept through representing general characteristics of reality. For instance, 'fatal', 'infectious' and 'disease' are mediate representations of the disease. These concepts represent the disease by representing general characteristics of the disease: being fatal, being infectious, being disease, and so forth. Here disease is abstract while suffering that a patient experiences is concrete. Notion is equated with 'pure concept', which is one of the two types of concept, the other being 'empirical concept'. Pure concept, independent of experience, is referred to as 'a priori' concept restraining sensation. Empirical concept obtained through experience is termed 'a posteriori' containing sensation. Essentially propensity of pure and empirical concepts engenders binary structure (Fogarty, 2005) producing univocal meaning (Guillemette \& Cossette, 2006). The concept disease signifies a type of realities that exists as pathos (suffering) and originates at the cellular level (Mitchell, 2015). Realities in a human life, according to binary tenet, are categorized into 'normal' and 'abnormal'; among them disease puts itself into abnormalities (Murphy, 1973). Proposition takes a form of statements or assertions expressing judgment or opinion to show the interrelationships among concepts. The statement - "pathogen is actively associated with disease" is a proposition which expresses a judgment and indicates a relationship between the concept 'pathogen' and the concept 'disease'. This is a 'cause' (pathogen) and 'effect' (disease) relationship. Relative truth value of proposition depends on the effectiveness of manipulations of concepts.

\subsection{Methodology}

Methodology exists in the theoretical premise and lets theory to be extended into practices (Halvorson, 2012). Practices involve the works on ideas already existed in researcher's mind and on representations containing researcher's sensation. Methodology is a means of cognition that offers a way of getting an intellectual (re)production of the subject (Howell, 2013). It sets principles and methods towards collation of preexisting concepts within the mind and information gained through the senses to constitute knowledge. In a research methodology is the logical condition that must be satisfied if the data are to be judged eventually relevant for the acceptance or rejection of an explanation or interpretation (Halvorson, 2012; Howell, 2013). The most of the notions of methodology make their two 
intrinsic facets visible - these are rationalism and empiricism. Rationalist claims emphasize the role of innate ideas, or a priori knowledge (Bourke, 1962) while empirical aspects concern experience, or a posteriori (Morick, 1980). Integrating two contrasting positions methodology lets the research beget knowledge by drawing on the collated preexisting concepts within the mind and information gained through the senses. At the foundation of methodology of cognition lie the objective laws of reality. Thus, in a research on public health a process objectively operates that logic and evidence are transformed into knowledge.

Review of literature (Beauchamp, 1995; Bhopal, 1999; Earle, Lloyd, Sidell, \& Spurr, 2007; Godfray, 2013; Guest, Ricciardi, Kawachi, \& Lang, 2013; Howell, 2013) unveiled few apparent understandings of methodology in public health. The domain of methodology in the discipline comprises of phenomena ranging from the molecular to the ecosystem level. The phenomena which are observed are related to several categories of reality including, for example, genetic, anatomical, physiological, micro organic, chemical, psychological, demographical, pathological, pharmacological, sociocultural, political-economic, ecological, policy and application, theoretical and philosophical. Among data some of which are gathered directly from phenomena through researchers' own sensations are 'primary data' while rests which are found in others' studies are classified as 'secondary data'. Further, qualitative/quantitative dichotomy is brought to a major division of data. Data carrying numerical nature are quantitative, on the other; data which are non-numerical and take shape of narrative are treated qualitative. Induction, deduction, interpretation, categorization, analogy, comparison, analysis and synthesis, these cognitive actions run throughout data processing that starts with presumption and ends with taking the inference.

\subsection{Instrumentation}

Knowledge cannot operate on its own rather has to involve instrumentation. Scientific theories referring to the Logic of Scientific Discovery of Popper (1935) are interpreted as [diverted to] practical instruments or tools for such purposes as the prediction of impending events. Concepts and theories are treated as merely useful instruments, and their worth is measured by how effective they are (Dewey, 1984). Urban (2008) outlines epistemological structure consisting of three distinct layers, where the professional body of knowledge is produced, transferred and applied. Instruments are used to diagnose, monitor and treat all medical abnormalities (Instructions for Authors, 2017). Therefore, a trait of the public health knowledge is that it transforms itself into the instruments to be produced and applied. 'Knowledge produced' is linked with methodology while 'knowledge applied' belongs to application. Instrumentation makes knowledge producible and applicable. In other words, reality is knowable and capturable then promotable through instrumentation. Hence, instrumentation comes to be meant as the course of action which - by using a set of instruments - brings human cognitive process and reality within the closest link and lets them operate towards producing knowledge and solving problem. It is notable that 'instrument' often is used as synonyms of 'apparatus', 'device', 'tool', 'technique', 'equipment' and 'method'.

Discussion continues by arbitrating name of what is at the heart of instrumentation as 
'problem'. It appears in public health with two distinct facets: the first is related to produced knowledge looking at gaps in knowledge that is, unknown or inadequately known reality. Knowledge gaps manifest themselves in questions using interrogative pronouns, determiners or adverbs, such as, what, who, which, why, when, where and how, which intend 'to know'. The second facet is linked with applied knowledge addressing abnormal states of health and people's needs to tackle unhealthiness - disease, and illness. In this regard, instrumentation internalizes aim 'to do' something for peoples towards adequate and effective solution. There are many instruments observed in Medical Instrumentation (2017), M. Susser and E. Susser (1996), Park (2013), Bhopal (1999), Earle, Lloyd, Sidell, and Spurr (2007), Halvorson (2012), Krug and Hepworth (1997), and Turnock (2016). The instruments which were identified could be put into four categories. First, surgical instruments work on the principle action of pharmacological and immunological by physical and mechanical means. The second category is used for diagnosis, screening and monitoring of diseases. Thirdly, equipments are useful to measure many electrical and chemical quantities based on different parameters such as temperature, pressure, viscosity/density, electric charge, frequency and chemical properties. Methods, the fourth category of instruments, are deployed to gather the data about health problem of people through interview, discussion with them and observation of situation.

\subsection{Application}

Every field of scientific knowledge has or has to have roles in solving problems and optimizing well-being in human lives (Fara, 2009). This narrative contributed to induce 'application' as a basic element. Application of knowledge about health, disease, illness and medicine inspired the journey of modern public health as a social action which started in the early 1800 s at the West (Aififi \& Breslow, 1994). During nascent industrialization, such social action was necessary for response to the situation of severe disease outbreaks in flock of urban slum people. Recent centuries are marked by tremendous medical advances and their applications (Jackson, 2011). Diseases that were previously deadly, have now become insignificant as modern medicine makes it so that we can easily fix, replace, or kill almost anything involving our bodies. Not only did application of knowledge affect world population allowing them to extend life expectancy_farther than previously thought possible, this element also moved public health towards higher levels.

The notions 'professionalism' (Larson, 1977; Slomka, Beth, DesVignes-Kendrick, \& Lloyd, 2008; Urban, 2008) and 'adaptation' (Brown, 1981; Brown, Inhorn, \& Smith, 1996) are at the center of understandings of application. The actual practice in a given profession is embedded in a system of knowledge production and application (Urban, 2008). Application is an attempt to translate one order of scarce resources - special knowledge and skills - into another - social and economic rewards (Larson, 1977). Thus, the concept of application in public health intrinsically derives from knowledge of public health (Slomka, Beth, DesVignes-Kendrick, \& Lloyd, 2008). It is engendered by the binary 'theory/practice' which often is replaced by 'basic/applied' and extended to 'problem/solution'. Practice appears as application of knowledge by drawing the sharp, widely known distinctions between itself and theory and privileges applied knowledge as usable and situation specific. The theory/practice dichotomy links well with a framework, where disease as a 'problem' - and the way it is 
defined - is distinct from its 'solution'. The role of the 'practitioners', in this framework, is to contribute to 'solving' a given problem by applying their specific knowledge, which they have acquired through formalized training (Urban, 2008).

Application so as to be understood, further draws on adaptation traits of human being as organism from an ecological perspective (Brown, 1981; Brown, Inhorn, \& Smith, 1996). There is a means where traits are tolerable or have minimally sufficient positive consequence to improve an organism's chances for survival in a particular environment. In the process of adaptation, particular traits are selected in a given environment since they increase organism's chances of survival and reproduction. As is implied, the environment sets certain 'problems' which organisms need to 'solve' and that natural selection is the mechanism by which such solutions are found. Disease is the primary environmental 'problem' and agent of natural selection. Though all organisms have biological, inborn adaptive traits, human beings are different from others. They contain volitional traits which run psychological and sociocultural processes against disease (problem). Despite this, people for many reasons cannot tackle disease and illness on their own. Hence, they have to depend on application of knowledge practice of public health.

\section{Conclusion}

In order to expound the ontology of public health from a perspective of university curriculum the paper has dealt with several relevant aspects including ontology and its importance, public health and its nature. Ontology has been conceptualized in three ways. It etymologically connotes the study of being. As a philosophical enterprise ontology looks at nature of reality. From a public health viewpoint ontology is the doctrine that refers to an understanding about basic elements theorized about. These concepts retain the importance that ontology is inevitable and effective in gaining insights into public health. Though there are several ideas, this study interests a notion which conceives public health as a distinct academic discipline. Intellectual constructions in public health are categorized as worldview, theory, methodology, instrumentation and application which are viewed as basic elements of the discipline. They are internalized in discipline's nature to be 'epistemic', 'interdisciplinary' and 'componential'.

What would be the possible approaches to developing an 'ontology of public health' curriculum for universities? What- and how- to teach the students? Admittedly, the answer to such questions could not be explored in this article. Further research - it is comprehensive is required that would cover both 'what' and 'how', content and pedagogy, of education on ontology of public health. Nevertheless, on judging the findings, this paper suggests few issues which would be relevant to and useful in developing the curriculum. These include (i) what ontology is and how public health, as an interdisciplinary field of knowledge, is grounded and founded on ontology. (ii) What the basic elements of public health are. (iii) How production of knowledge is linked with intellectual constructions, e.g. concepts, notions, categories, schema, models and signs. (iv) How to perform public health research and practice from the ontological perspective. 


\section{Acknowledgements}

I am deeply indebted to Professor Dr. Farzana Islam, Vice Chancellor, Jahangirnagar University. She made this research possible by providing me with scope for teaching ontology of public health. In writing this article I got advisory support from Dr Mohammad Shah Jalal, Professor, Department of Anthropology at Jahangirnagar University; and assistances from Early Concern, a research organization in Bangladesh. Moreover, cooperation of colleagues and students (specially $45^{\text {th }}$ batch) at the Department of Public Health and Informatics, Jahangirnagar University were significantly useful. I owe much to all of them.

\section{References}

Achinstein, P., \& Barker, S. F. (1969). The Legacy of Logical Positivism Studies in the Philosophy of Science. Baltimore: Johns Hopkins University Press. Retrieve from http://www.journals.uchicago.edu/doi/10.1086/350631

Afifi, A. A., \& Breslow, L. (1994). The Maturing Paradigm of Public Health. Annual Review of Public Health, 15, 223-235. https://doi.org/10.1146/annurev.pu.15.050194.001255

Audi, R. (1999). The Cambridge Dictionary of Philosophy. Cambridge: Cambridge University Press. Retrieve from https://is.muni.cz/el/1421/podzim2014/LJMgrB07/um/Cam bridge_Dictionary_of_Philosophy.pdf

Ausburg, T. (2016). Becoming Interdisciplinary: An Introduction to Interdisciplinary Studies. New York: Kendall Hunt. Retrieve from https://he.kendallhunt.com/product/becoming-inter disciplinary-introduction-interdisciplinary-studies

Bailey, N. (1721). An universal etymological English dictionary. London: T. Osborne. Retrieve from https://ia902606.us.archive.org/32/items/universaletymolo00bail/universalety molo00bail.pdf

Beauchamp, D. E. (1995). Philosophy of public health. In W. T. Reich (Ed.), Encyclopedia of bioethics. New York: Simon and Schuster MacMillan.

Becher, T., \& Trowler, P. R. (2001). Academic tribes and territories: intellectual enquiry and the culture of Disciplines. Buckingham: SRHE. Retrieve from https://www.cs.kent.ac.uk/ people/staff/saf/share/great-missenden/reference-papers/BecherTrowlerExtract.pdf

Bhopal, R. (1999). Paradigms in Epidemiology Textbooks: In the Footsteps of Thomas Kuhn. American Journal of Public Health, 89(8), 1162-1165. https://doi.org/10.2105/AJPH. 89.8.1162

Bourke, V. J. (1962). Rationalism. In D. D. Runes (Ed.), Dictionary of Philosophy. Totowa: Littlefield, Adams, and Company.

Brown, P. J. (1981). Cultural adaptations to endemic malaria in Sardinia, Medical Anthropology, 5(3), 313-339. Retrieved from http://www.tandfonline.com/doi/abs/10.1080/ 01459740.1981 .9986991 


\section{Macrothink}

Brown, P. J., Inhorn, M. C., \& Smith, D. J. (1996). Disease, Ecology, and Human Behavior. In C. F. Sargent \& T. M. Johnson (Eds.), Medical Anthropology: Contemporary Theory and Method. London: PRAEGER.

CDCF. (2016). What is Public Health? Retrieve from http://www.cdcfoundation.org/content/ what-public-health

Cole, P. (1995). The moral bases for public health interventions. Epidemiology, 6(1), 78-83. Retrieve from http://journals.lww.com/epidem/Citation/1995/01000/THE_MORAL_BASES_ FOR_PUBLIC_HEALTH_INTERVENTIONS_.16.aspx

Critique of Pure Reason. (2017). Wikipedia. Retrieved from https://en.wikipedia.org/w/index. php?title=Critique_of_Pure_Reason\&oldid $=765247423$

Dawson, A. (2009). Introduction: the Philosophy of Public Health. In A. Dawson (Ed.), The Philosophy of Public Health. Surrey: Ashgate. https://doi.org/10.1057/9780230582545_1

Dewey, J. (1927). The Public and Its Problems. Chicago: Swallow Press.

Dewey, J. (1984). Boydston. In J. Ann (Ed.), John Dewey: The Later Works, V. 2. Carbondale: Southern Illinois University Press.

Earle, S., Lloyd, C. E., Sidell, M., \& Spurr, S. (2007). Theory and Research in Promoting Public Health. New Delhi: SAGE.

Fara, P. (2009). Science: A four thousand year history. Oxford: Oxford University Press.

Feynman, R., Leighton, R., \& Sands, M. (2013). The Feynman Lectures on Physics. Retrieved from http://feynmanlectures.caltech.edu/I_toc.html

Fogarty, S. (2005). Binary Oppositions. The Literary Encyclopedia. London: Literary Dictionary Company.

Forest, J., \& Kinser, K. (2002). Higher Education in the United States: An Encyclopedia. Santa Barbara: ABC-CLIO.

Frolov, I. (1984). Dictionary of Philosophy. Moscow: Progressive Publishers.

Gifford, F. (2011). Philosophy of Medicine. Amsterdam: Elsevier. https://doi.org/10.1016/ b978-0-444-51787-6.50001-5

Gilman, N. V. (2017). Analysis for Science Librarians of the 2016 Nobel Prize in Physiology or Medicine: The Life and Work of Yoshinori Ohsumi. Science \& Technology Libraries, 36(1), 1-19. https://doi.org/10.1080/0194262X.2016.1273814

Godfray, H. C. J. (2013). Mosquito ecology and control of malaria. Journal of Animal Ecology, 82(1), 15-25. https://doi.org/10.1111/1365-2656.12003

Godfrey-Smith, P. (2003). Theory and Reality. Chicago: University of Chicago. https://doi.org/10.7208/chicago/9780226300610.001.0001

Grayling, A. C. (1998). Philosophy 1: A Guide through the Subject. Oxford: Oxford 
University Press.

Grayling, A. C. (2001). An Introduction to Philosophical Logic. Hoboken: Wiley.

Guest, C., Ricciardi, W., Kawachi, I., \& Lang, I. (2013). Oxford Handbook of Public Health Practice. Oxford: Oxford University Press. https://doi.org/10.1093/med/9780199586301. 001.0001

Guillemette, L., \& Cossette, J. (2006). Deconstruction and difference. Retrieved from http://www.signosemio.com/derrida/deconstructionanddifferance.asp

Halvorson, H. (2012). What Scientific Theories Could Not Be. Philosophy of Science, 79(2), 183-206. https://doi.org/10.1086/664745

Harper, D. (2001). Online Etymology Dictionary. Retrieved from http://www.etymonline.com Hatch, J. A., \& Barclay-McLaughlin, G. (2006). Qualitative Research: Paradigms and Possibilities. In B. Spodek \& O. Saracho (Eds.), Handbook of Research on Education of Young Children. Mahwah: Lawrence Erlbaum.

Hill, W. H. (1822-1907). Elements of Philosophy. Baltimore: J. Murphy.

Hornby, A. S. (2010). Oxford Advanced Learner's Dictionary of Current English. New York: Oxford University Press.

Howell, K. E. (2013). Introduction to the Philosophy of Methodology. London: Sage. https://doi.org/10.4135/9781473957633

Howick, J. (2011). The Philosophy of Evidence based Medicine. Hoboken: Wiley. https://doi.org/10.1002/9781444342673

Hughes, P., \& MacNaughton, G. (2000). Consensus, Dissensus or Community: The politics of parent involvement in early childhood education. Contemporary Issues in Early Childhood, l(3), 241-258. https://doi.org/10.2304/ciec.2000.1.3.2

IM. (1988). The Future of Public Health. Washington, DC: National Academics Press.

Instructions for Authors. (2017). Medical Instrumentation. Retrieved from http://www.hoajon line.com/medicalinstrumentation/authors

Islam, Z. (2000). Language and Its Influence in Shaping the Outputs of Qualitative Health Research. Paper accepted by the 6th Qualitative Health Research Conference, 6- $8^{\text {th }}$ April 2000 at University of Alberta, Canada.

Jackson, M. (2011). Introduction. In M. Jackson (Ed.), The Oxford Handbook of the History of Medicine. Oxford: Oxford University Press. https://doi.org/10.1093/oxfordhb/97801995 46497.001.0001

Jones, K. L., Shainberg, L. W., \& Byer, C. O. (1985). Health Science. New York: Harper \& Row.

Kirmayer, L. (1988). Mind and Body as Metaphors: Hidden Values in Biomedicine. In M. 


\section{Macrothink}

Journal of Educational Issues

ISSN 2377-2263

2017, Vol. 3, No. 1

Lock \& D. R. Gordon (Eds.), Biomedicine Examined. Dordrecht: Kluwer Academic Publishers. https://doi.org/10.1007/978-94-009-2725-4_4

Klages, M. (2007). Literary Theory: A Guide for the Perplexed. London: Continuum Press.

Kreiger, N., \& Brin, A. E. (1998). A Vision of Social Justice as the Foundation of Public Health: Commemorating 150 years of the spirit of 1848. American Journal of Public Health, 88(11), 1603-1606. Retrieved from http://ajph.aphapublications.org/doi/abs/10.2105/AJPH. 88.11 .1603

Krug, G., \& Hepworth, J. (1997). Poststructuralism, qualitative methodology and public health: research methods as a legitimation strategy for knowledge. Critical Public Health, 7(1-2), 50-60. https://doi.org/10.1080/09581599708409078

Kuhn T. S. (1996). The Structure of Scientific Revolutions. Chicago: Chicago University Press. https://doi.org/10.7208/chicago/9780226458106.001.0001

Lamanna, M. (2006). Correspondences between the works of Lorhard and Timpler. Bari: Bari University.

Larson, M. S. (1977). The rise of professionalism: A sociological analysis. Berkeley: California University Press.

Lewis, C. T., \& Short, C. (1879). A Latin Dictionary. Oxford: Clarendon Press.

Lindberg, D. C. (2007). The beginnings of Western science: The European Scientific tradition in philosophical, religious, and institutional context. Chicago: Chicago Press University.

Luchte, J. (2007). Kant's Critique of Pure Reason. London: Bloomsbury Publishing.

Martin-Moreno, J. M. (2015). Self-assessment tool for the evaluation of essential public health operations in the WHO European Region. Copenhagen: WHO. Retrieved from http://www.euro.who.int/_data/assets/pdf_file/0018/281700/Self-assessment-tool-evaluation -essential-public-health-operations.pdf?ua $=1$

Mitchell, R. N. (2015). The Cell as a Unit of Health and Disease. In V. Kumar, A. K. Abbas, \& J. C. Aster (Eds.), Robbins and Cotran Pathologic Basis of Disease. Philadelphia: Elsevier.

Morick, H. (1980). Challenges to Empiricism. Indianapolis: Hackett Publishing.

Murphy, E. A. (1973). The normal. American Journal of Epidemiology, 98(6), 403-411. https://doi.org/10.1093/oxfordjournals.aje.a121569

Muthu, V. K. (2014). A Short Book of Public Health. London: J. B. Medical.

Nijhuis, H. G. J., \& van der Maesen, L. J. G. (1994). The philosophical foundations of public health: An invitation to debate. Journal of Epidemiology and Community Health, 48, 1-3. https://doi.org/10.1136/jech.48.1.1-a

Øhrstrøm, P., Schärfe, H., \& Uckelman, S. L. (2008). Jacob Lorhard's Ontology: A $17^{\text {th }}$ Century Hypertext on the Reality and Temporality of the World of Intelligibles. In S. L. 
Uckelman (Ed.), Diagraph of Metaphysics or Ontology - Jacob Lorhard, 1606. Retrieved from http://staff.science.uva.nl/ suckelma/lorhard/lorhard-english.html

Park, K. (2013). Park's Textbook of Preventive and Social Medicine. Jabalpur: Banarsidas Bhanot.

Pickering, M. (2006). Auguste Comte: An Intellectual Biography (Vol. I). Cambridge: Cambridge University Press.

Popper, K. (1935). Logic of Scientific Discovery. London: Routledge.

Reynolds, P. D. (1971). A primer in theory construction. Boston: Allyn and Bacon.

Rudnick, A. (2004). An introductory course in philosophy of medicine. Medical Humanities, 30(1), 54-56. https://doi.org/10.1136/jmh.2003.000154

Shattuck, L. (1850). General Plan for the Promotion of Public and Personal Health. Boston: Dutton \& Wentworth.

Simons, P. (2017). Ontology. Encyclopedia of Britannica. Retrieved from https://global. britannica.com/topic/ontology-metaphysics

Slomka, J., Beth, Q., DesVignes-Kendrick, M., \& Lloyd, L. E. (2008). Professionalism and Ethics in the Public Health Curriculum. Public Health Reports, 2(123), 27-35. https://doi.org/10.1177/00333549081230S205

Susser, M., \& Susser, E. (1996). Choosing a future of epidemiology, I: Eras and paradigms. American Journal of Public Health, 86, 668-673. https://doi.org/10.2105/AJPH.86.5.668

Teichmann, J., \& Evans, K. C. (1999). Philosophy: A Beginner's Guide. Oxford: Blackwell.

Timpler, C. (1604). Metaphysicae Systema Methodicum. Steinfurt.

Turnock, B. J. (2016). Essentials of Public Health. Burlington: Jones \& Bartlett Learning.

Urban, M. (2008). Dealing with uncertainty: challenges and possibilities for the early childhood profession. European Early Childhood Education Research Journal, 16(2), 135-152. https://doi.org/10.1080/13502930802141584

van der Maesen, L. J. G., \& Nijhuis, H. G. J. (2000). Continuing the debate on the philosophy of modern public health: Social quality as a point of reference. Journal of Epidemiology and Community Health, 54, 134-142. https://doi.org/10.1136/jech.54.2.134

Warren, J. C., \& Smalley, K. B. (2014). Introduction. In J. C. Warren \& K. B. Smalley (Eds.), Rural Public Health Best Practices and Preventive Models. New York: Springer.

Weed, D. L. (1999). Towards a philosophy of public health. Journal of Epidemiology and Community Health, 53(2), 99-104. https://doi.org/10.1136/jech.53.2.99

WHO. (2016). Public Health. Retrieved from http://www.who.int/trade/glossary/story076/en

Williams, W. C. (1991). Abstract Meditations on the Concrete and Concrete Implications for 


\section{Macrothink}

Journal of Educational Issues

ISSN 2377-2263

2017, Vol. 3, No. 1

Mathematics Education. In I. Harel \& S. Papert (Eds.), Constructionism. Norwood: Ablex Publishing. Retrieved from https://ccl.northwestern.edu/papers/concrete

Winslow, C.-E. A. (1920). The Untilled Field of Public Health. Modern Medicine, 2, 183-191. https://doi.org/10.1126/science.51.1306.23

Winslow, C.-E. A. (1926). Public Health at the Crossroads. American Journal of Public Health, 16(11), 1075-1085. https://doi.org/10.2105/AJPH.16.11.1075-a

\section{Copyright Disclaimer}

Copyright for this article is retained by the author(s), with first publication rights granted to the journal.

This is an open-access article distributed under the terms and conditions of the Creative Commons Attribution license (http://creativecommons.org/licenses/by/3.0/). 